\title{
SECULAR PILGRIMS ON THE QUEST FOR AUTHENTICITY? ${ }^{1}$
}

\author{
Tom SELÄNNIEMI \\ The Finnish University Network for Tourism Studies \\ FIN-57101 Savonlinna, POB 126, Finland

\section{INTRODUCTION: TWO WAYS OF LOOKING AT THE TOURIST}

In this paper I will explore the relation between the tourist and the place visited drawing on my own fieldwork among Finnish tourists in many Mediterranean tourist destinations, like Athens and Rhodes in Greece and Bodrum in Turkey, as well as Gran Canaria in Spain and Aqaba in Jordan. I will show that the tourists' relations to the place visited varies very much. In some types of recreational mass tourism to beach resorts the local heritage or the spirit of place is of marginal importance. In other types of tourism, like cultural tourism to Athens, the importance of the place is central to the tourist experience and, thus, the journey can be described as a secular pilgrimage.

In the paper I will from an emic perspective analyse the tourists' experiences and compare cultural tourism to beach tourism in order to cast light on the tourists' own experiences in both types. This analysis casts doubts on what could be called the "authenticity paradigm" in the anthropology and sociology of tourism. The aim of the paper is to enhance our understanding of different types of tourism, and especially to explore the tourists' experiences in both site-oriented (heritage, cultural) tourism and image-oriented (beach, recreation) tourism.

Tourism to the Mediterranean region and the Canary Islands has become an integral part of modern Finnish culture, which is indicated by the adoption of special terms into the spoken language. Finns very often refer to their holiday destinations with the concept "etela" (=south) without clarifying more exactly what geographical place they are talking about. Common phrases are "kavimme etelassa lomalla" (we went to the south on our holiday), "lahden etelanmatkalle" (I will go to the south), etc. The concept "etela" is widely used also in tourism marketing, especially in newspaper advertisements, sometimes without any clear indications of where this "south" is. (SELÄNNIEMI 1994b; 1996).

The difference between the destinations I studied as well as the tourists travelling to these destinations comes forth very clearly in the motives for choosing a certain destination. When I asked tourists in my field work destinations why they had chosen this one, only the tourists in Athens (67\%) and Aqaba (46\%) answered that

1 An earlier version of this paper was presented at the "Very much abroad - but why? Art and travel before and after 1900” symposium, Joensuu, September 10-12, 1998. 
their main singular motive for choosing the destination was the place's culture or history. For the tourists in the other destinations the culture and history had no importance. Instead, motives that are interchangeable between any tourist destination in the "south", were given as answers to the open question in the questionnaire. The sun and the climate, familiarity of the place and suitability of the flight or date of departure are motives for destination choice that are not related culturally or geographically to any specific location.

What I will attempt to do in this paper is to portray the two major paradigmatic approaches to tourism in the sociology and anthropology of tourism and - if possible - try to overcome some of the shortcomings in the present literature on tourism.

\section{THE SACRED SITE}

Sites are never simply locations. Rather they are sites for someone and of something. The cultural context of images and myths adds a socially constructed level of meaning to the 'genius loci' the classics, 'unique sense of place', said to derive from the forms of the physical environment in a given site (SHIELDS 1991: 6).

The meaning of a place is a sum of intersubjective and cultural interpretations. Thus the same place might once have been considered to be sacred by a local community, and now exotic and attractive as a tourist resort by tourists and tour agencies, where the sacred elements have been disconnected from the cultural systems of meanings and moved into a museum (SHIELDS 1991). Moreover, each person constructs an individual meaning of a place in a similar process. Thus the meaning of the Acropolis in the minds of tourists is a compendium of the information they have about the hill and the things they observe on the hill. As the sum of these interpretations the Acropolis has a different meaning for different tourists. (SELÄNNIEMI 1994a).

If some tourists can be likened to pilgrims, then the attractions that draw tourists must have something in common with sacred sites. As Emile DURKHEIM (1980 [1912]), Arnold VAN GENNEP (1960 [1908]) and many others have shown, the sacred things, objects, places and phenomena, form a category by which society deals with and classifies reality. Sacredness is an expression of a special value attached to objects or sites. By the same logic it can be presumed that in modern context the tourist attractions must have certain features that distinguish them from sites and objects that people confront in everyday life, if tourists are to travel to see the attractions (URRY 1990: 11).

Veikko Anttonen has shown that in traditional societies the sacredness of a place or a thing was determined by its anomaly and liminality. The cultural discourse on the sacred-making characteristics of time, places, or objects is always based on the need to mark meaningful relations in moments of transformations in cultural value categories (ANTTONEN 1992). According to Catherine Joanne SCHMIDT 
(1991) tourist attractions are extreme phenomena. They may be the biggest, oldest, best, rarest etc in their field. Schmidt writes:

From all the possible objects and events in our universe, the marginal and transitional ones phenomenologically appear to us as most important and sacred (against a field of the ordinary and profane); these sacred pockets draw our attention in a modern-day ritual - the ritual of sightseeing... (SCHMIDT 1991: 109).

The objects or sites that are deemed sacred or chosen as tourist attractions are in a way something more than similar objects or sites that are not sacred or attractions. The sacredness or value of being worth seeing is a value attached to an object through a socially constructed process (see ELIADE 1979 on this). The main analogy between a sacred object or site and a sight is that both are agreed upon in a culture. The objects are chosen by society to be sacred or sights (often both). A society, a group or an institution agrees that a certain object is worth seeing, that it is a sight, for example because of historical, political, artistical or social reasons. In the same way a culture or its religious leaders may canonize saints or declare sites to be sacred. Tourists travel to see the sights because it is generally agreed in their culture that these sights are worth seeing. Religious pilgrims travel to sites that are considered sacred in their religion.

The analogy between a sacred site and a (sacred) sight, in this case the Acropolis, could be presented as follows in a model developed by the author in collaboration with Veikko Anttonen:

\begin{tabular}{|c|c|c|}
\hline MARKER & SACRED SITE & (SACRED) SIGHT \\
\hline MEANING & $\begin{array}{l}\text { The expression of traditional } \\
\text { value categories (Sacredness) }\end{array}$ & $\begin{array}{l}\text { The indication of the value } \\
\text { of travelling (Value of being } \\
\text { worth seeing) }\end{array}$ \\
\hline $\begin{array}{l}\text { THE GIVER } \\
\text { OF MEANING }\end{array}$ & Local culture, religion & Western (touristic) culture \\
\hline $\begin{array}{l}\text { CANON } \\
\text { (SOURCE OF MEANING) }\end{array}$ & $\begin{array}{l}\text { Narrative, tradition, sacred texts, } \\
\text { mythology (in some cases of several } \\
\text { religions, e.g. Jerusalem) }\end{array}$ & $\begin{array}{l}\text { Guide books, travelogues, } \\
\text { advertisements, education }\end{array}$ \\
\hline RITUAL & Pilgrimage & $\begin{array}{l}\text { Tourism (oriented to a } \\
\text { certain site) }\end{array}$ \\
\hline $\begin{array}{l}\text { FORMS OF CONTACT } \\
\text { (OTHER RITUALS) }\end{array}$ & $\begin{array}{l}\text { Religious rituals, ceremonies, } \\
\text { worship, sermon, offerings, song, etc. }\end{array}$ & $\begin{array}{l}\text { Touristic rituals, like the speech } \\
\text { of the guide, sightseeing, } \\
\text { photographing and reading } \\
\text { the guidebooks }\end{array}$ \\
\hline AIM & $\begin{array}{l}\text { Transformation, the renewal and } \\
\text { confirmation of value categories }\end{array}$ & $\begin{array}{l}\text { Transformation, the renewal and } \\
\text { confirmation of value categories }\end{array}$ \\
\hline
\end{tabular}


In this analogy the sacred site and the sight are signifiers or markers that refer to the cultural meaning of the site or sight, that is, the expression of value categories. The local (traditional) culture or the general western cultural tradition gives meaning to the site or sight. The resource for the meaning, or the canon, is the traditional narrative in the first case and the touristic narrative in the second. The canon and the western (touristic) culture can be understood as markers for the sight in MACCANNELL's (1989) definition of the tourist attraction, but the sight itself functions also as a marker or signifier for the expression of values connected with travelling. The most conspicuous ritual in both cases is the type of journey, pilgrimage or tourism, undertaken in order to reach the sacred site or sight. The other rituals performed in the vicinity to the site or sight could be described as forms of contact or communication with it. In both cases the aim for the journey to the site or sight is a transformation, a renewal of value categories or the confirmation of existing ones. When we look at the sacred site from a theological perspective the site is sacred. The believers do not see the site as a marker of the relations in the above model. Similarly, the tourists are not often aware of the sight as a marker for the above relations, but take for granted that the sight is worth seeing. Visiting the Acropolis is an expression of the values of travelling in our western culture in a similar way as performing rituals at a sacred tree is an expression of traditional value categories in a local culture. (SELÄNNIEMI 1994a).

Victor and Edith TURNER (1978) think that some form of conscious travelling to a distant place, which is closely connected to some central values, seems to be culturally universal. It can be sustained by religious or secular sanctioning, guiding and encouraging. The national pilgrimages, as in the United States during the bicentennial, or political pilgrimages to the Lenin mausoleum in the former Soviet Union are secular pilgrimages. (TURNER-TURNER 1978: 241). Secular pilgrimages to sites that reflect central historical, cultural, social, political, etc. values to individuals, groups and societies are part of modern tourism.

\section{THE GAZING TOURIST}

The famous art historian E.H. Gombrich has written that "looking is to seeing what listening is to hearing", and continues:

The eye is not a passive but an active instrument, serving a mind that must be selective if it is not to be swamped by a flood of indigestible messages. Seeing is always looking for something, comparing, interpreting, probing and disregarding. (GOMBRICH 1979: 199).

The tourists look at objects in the museums of Athens and buildings on the Acropolis in mainly two ways. The first type of looking could be called the travelling eye and the second type the fastening gaze. The travelling eye wanders over the landscape or view without fixing on details or objects if they are not special in some way 
or interesting to the tourist. This type of gaze looks for the impression of a place, not for specific information about a place. The fastening gaze focuses on details, looking for information and observing the objects. It does not wander like the travelling eye, it moves from one object or detail to another. In museums and on archeological sites the fastening gaze is characteristic of the cultural tourists and the pilgrims, and the travelling eye of the holiday makers. In the old town of Athens, the Plaka, and especially on the streets with souvenir shops, on the hyperpolished streets of Playa del Ingles, and in the towns of Aqaba, Bodrum and Rhodes, almost all tourists have a travelling eye. The two ways of looking at objects are related to the different backgrounds of the tourists. In order to be able to read the display in a museum or the ruins on Acropolis, in Ephesus or Petra, the tourists need some kind of information about what they look at. The speech of the tour guide or the text in the guidebook, if used as the only information, produces mostly the travelling-eye-type of looking. The more thorough the preparation for confronting the sight is the more intense the gaze will develop. An education in for instance art history or the history of ancient Greece in the case of the Acropolis gives more significance to the sight in the tourists eyes, and thus produces a gaze interested in details and information: the fastening gaze. These observations on the way tourists look at objects and places surrounding them accord with what John URRY (1992) has presented on a more theoretical macrolevel. The fastening gaze is close to what URRY calls the romantic gaze, and the travelling eye is related to the collective tourist gaze (SELÄNNIEMI 1996).

When cultural tourists or pilgrims walk into a room in the National Archeological Museum in Athens, they first take an overall impression of the room before fixing their gaze upon an exhibit and start walking towards it. The gaze is fastened upon a statue or some other exhibit, leaving it only for reading about the object of the gaze in the guidebook or on the label attached to the object (i.e. the marker). When the tourists have seen enough of the exhibit, they fasten their gaze upon the next exhibit and walk towards it, often consulting their guidebooks for detailed information about it. (SELÄNNIEMI 1996).

The holiday maker walks through the museum room letting his eyes wander over the objects without fixing the gaze unless something really conspicuous or spectacular meets the eye. In the National Archeological Museum the main eye catchers are for instance the golden death-masks from Mycenaean tombs found by Heinrich Schliemann, one of which is the so-called mask of Agamemnon. In room 21, the eye is caught by the bronze statue of a horse with the little rider, and in room 15 by the bronze Poseidon, which seems to look back at the beholder, and is probably the most gazed exhibit in the museum - if the gaze is measured with its intensity and duration.

The travelling eye of the tourists walking the streets of Plaka, is fixed only if the eye meets something outside the tourist's ordinary experience. In Plaka one often sees dogs lying in the middle of the streets and one of the souvenir shops on Adrianou street has a cat that usually sleeps on the bags with Parthenon embroidered on one side. When the tourist meets these sights, the eye is suddenly fixed upon the dog or cat that is behaving differently than dogs or cats back home, and usually the mechanical device for fastening the gaze, the camera, is used to record this special view. 
Thus ordinary things, in this case ordinary pets, seen in a strange setting, and maybe behaving in a way the tourists aren't used to, function as an eye catcher. In order to catch the eye the detail or event has to differ sufficiently from the tourist's ordinary experiences, it has to be judged worth seeing.

In Rhodes tourists very often walk around the old town with the travelling eye focusing only on objects for sale on Socratous street. Few tourists stop at the end of Ippoton, one of the best preserved medieval streets of Europe, and if they stop, it is only to take a photo with someone posing in front of the view. In the observation material from Rhodes there are only a few examples of tourists that obviously are aware of the historical importance of the medieval town of Rhodes and come for instance to the Ippoton in order to see it. In Playa del Ingles there is not really anything to see, so the tourists just wander around the town if they even bother to come to the center. The old town of Bodrum has not much to offer the eye except the fortress of the knights of St. John and the totally ruined Mausoleum of ancient Halicarnassus. In Aqaba the gaze might fasten on the different way of life, but the real eye-catcher is Petra two hours coach-ride away. There the gaze of the tourists fastens on both the ancient buildings of the Nabateans and also on the spectacular colours and forms of the sandstone rocks and mountains. In Petra happens the same thing that sometimes happens on the Acropolis. The tourists touring with the travelling eye meet something so spectacular, the confrontation with the sight is so impressing, that it forces the tourist to fasten the gaze on things surrounding him/her. Naturally this does not always happen. The "holiday makers" very often walk through the Acropolis, Ephesus or Petra taking some snapshots with the companion posing in front of a temple or sitting on a camel, and looking at something but not really seeing anything, with their minds on the lunch stop, the closest toilet or (to put it sarcastically) grieving over the loss of one sunny day on the beach.

\section{A DIFFERENT ACROPOLIS FOR DIFFERENT TOURISTS}

The behaviour of the holiday makers and the pilgrim-tourists on the Acropolis is clearly differentiated. They do look at the same sight but they see it differently. By using Dean MACCANNELL's definition of the tourist attraction (1989) as an analytical model we can see that the three different types of tourists do not gaze at the same Acropolis. MacCannell defines a tourist attraction as an empirical relationship between a tourist, a sight and a marker. The structure of a tourist attraction can be visually presented (Fig. 1).

In this definition the sight is purely a physical object or site and the marker a piece of information about the sight which tells the tourist that the sight is in some way worth seeing. The markers may take many different forms: guidebooks, information tablets, the speech of the tour guide, advertisements, etc. We can use this 


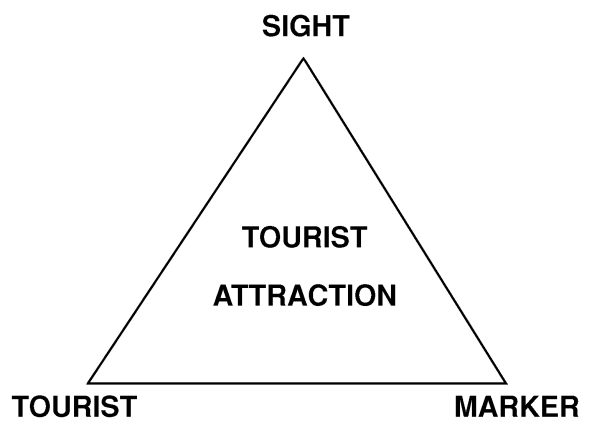

Fig. 1. Structure of a tourist attraction

triangular model as a game by putting different types of tourists in one corner, different kinds of markers - the markers most probable for the tourist - in the other corner of the triangle and a sight as a pure object without any values attached to it in the third corner. In this model I treat the values attached to objects making them worth seeing as markers. By playing the game this way, keeping the sight at its place but changing tourist types and markers, the end result, the tourist attraction always looks different. (SELÄNNIEMI 1994a).

The Acropolis is different for the three tourist types because the markers and the interests of the tourists are different. For the "holiday maker" the only markers may be the advertisements or the speech of the tour guide. The "cultural tourists" and the "pilgrims" have guidebooks, literature about the ancient Greek culture and education, among other things, as markers. In this way the Acropolis can be boring ruins for some tourists and a goal for a secular pilgrimage for others (SELÄNNIEMI 1994a).

For the common vacationer, the Acropolis is just a sight among others, a site to which the tourist climbs in order to spend his time between other numbers on the itinerary. The round is made in a relatively short time with a travelling eye, and, as a proof of "doing" the Acropolis, a photo is taken with the tourist posing in front of the Parthenon or the Charyatides. The holiday makers seldom use guidebooks, because detailed information about the hill is of marginal importance to them. It is enough to "do" the Acropolis (SELÄNNIEMI 1994a).

At the opposite end of the continuum the pilgrim-tourists take the Acropolis more seriously. They recognize the historical and artistical heritage and value of the hill. The walk around the temples is made very thoroughly, even with devotion, fastening their gaze upon details and reading their guidebooks silently for themselves or aloud for their companions. As Donald HORNE (1984: 1) describes this group:

Devotees of the cult are often seen in the great churches of Europe. You know them by the long, thin books they carry, bound in green or maroon. Sometimes they walk the aisles, studying the printed pages. Sometimes they sit, lips moving as they pass on the words to fellow-devotees; 
or they read silently, in private contemplation. From time to tome some look up towards a part of the church, although they seem regretful about looking away from the print. The books are Michelin Guides. The devotees are tourists. They are trying to imagine the past. (HORNE 1984: 1).

The pilgrim-tourists take photos only of the buildings on the site, and possibly of the view over the other sites of antiquity visible from the hill. A very striking feature of the pilgrim-tourists' way of taking photos is that they want to have only the pure object itself, that is the building, a detail of it, a statue, etc. without any people around spoiling the picture. They focus their long lenses on details of the temples and wait with patience for the view to be clear of tourists (SELÄNNIEMI 1994a).

The visit of the "holiday maker" to the Acropolis could be described as a hollow ceremony, an obligatory part of the itinerary when one is in Athens. The pilgrimtourists' devotional visit is more like a ritual performed in honour of the symbolic values of the Acropolis which the tourists regard as central. The "cultural tourists", the largest group of the Finnish tourists in Athens are somewhere between these two extremes. They too recognize the values of the Acropolis and perform a touristic ritual on it, but the Acropolis has not been their main reason for travelling to Athens. These different attitudes and reactions towards the Acropolis can be stated also in terms of how these tourists relate themselves to the cultural heritage of the Europeans. The Acropolis is considered by the pilgrim-tourists and cultural tourists to be a part of their common European heritage - a part of the educated middle class heritage, but the holiday makers do not relate themselves so intimately with the same site. With the lower education of the holiday makers they might not see the link between themselves and the heritage of ancient Greece in the same way as the pilgrims and cultural tourists.

\section{THE SENSING, PLAYFUL TOURIST}

Everything in mass tourism is not about looking at places, or to put it more exactly, to see places. The sense of sight is not exclusive in experiences of the vacation. The tourists seem to enjoy pleasures derived from tactile stimuli of a very basic nature, like heat or the cooling seawater on your skin. These are pleasures we do not necessarily experience or pay attention to in everyday life, or we do not have time to stop to enjoy them. As Pasi FALK (1994: 2) has written: "the human body as a sensory and sensual being presupposes always (already) its counterpart, the 'sensible' body, that is, a body subsumed to a cultural Order - both symbolic and practical defining its boundaries and its position in the larger whole (community or society)". Maybe the transition from home to the south in suntourism could be understood also as a transgression of the boundaries of the sensible body. My analysis on Finnish tourism to Playa del Ingles, Rhodes and Bodrum accentuates the point made by Soile VeIJOLA and Eeva JoKInEN (1994) that the tourist's body is largely absent in 
studies on tourism. Focusing on the tourist gaze (URRY 1990) or on MACCANNELL's $(1973 ; 1989)$ theories based on the primacy of visual stimuli in the tourist experience is not sufficient in analysing this type of suntourism to beach resorts.

The tourist experiences the "south" synesthetically. On different occasions different senses take priority over the others, but the tourist experience is very seldom purely aesthetical as the above mentioned theories largely claim (cf. JOKINEN and VEIJOLA 1994). A simple example clarifies this well: Turn on your television set and video unit and play a tape with views from a strange location but turn the volume to zero. Have you experienced anything like this when you have been a tourist? The closest you might get would be touring a place in a fully air-conditioned bus just driving past places never stopping and getting outside the bus. As soon as the bus stops and opens its doors local odours, noise and temperature can be sensed. When you step out you can immediately feel the intense sunshine and heat on your skin (if we pretend that the bus is driving for instance in Rhodes at summertime), you can smell the wonderful odours of the nearby tavern preparing dolmades and moussaka alongside the smell of the neighbouring butcher's gutter that makes you a bit nauseous. You feel the grip of the souvenir seller, when he directs you into his shop and taste the ouzo he is offering you. After the round-trip you feel hot and dirty on your skin and decide to take a dip in the sea, which feels nicely cooling on the skin. You forget to take a shower after swimming in the sea water, so after a while in the sun you feel much more unpleasant sensations on your skin. After greasing your back (or somebody else has spread lotion on it $=$ more tactile stimuli), you decide to leave the beach and have dinner, where your senses of taste and smell are once more activated. Finally you experience a "bodily communitas" in a nearby disco before returning back to the hotel, alone or with someone.

A good clue to understanding the phenomenon of mass tourism comes from the anthropological theories on the ritual process, especially the writings on transition rites by VAN GENNEP $(1960 ; 1908)$ and TURNER (1978). In transition rites, of which initiations are a case in point, the ritual subjects go through phases that are called preliminal, liminal, and postliminal. The preliminal is the normal profane state of being, the liminal phase is sacred, anomalous, abnormal and dangerous, and the postliminal is the normal state of things to which the ritual subject re-enters after the transition. The liminal is a state and a process in the transition phase during which the ritual subjects pass a cultural area or zone that has minimal attributes of the states preceding or following the liminal. This "betweenness" has been compared to eg. death, bisexuality and invisibility. (TURNER and TURNER 1978). Nelson GRABURN (1989) has, by using LEACH's (1982) refinements on van Gennep's and Turner's theories, shown how tourism can be understood as a journey to the sacred in an analogy with transition rites.

The stage in tourism that resembles the liminal stage or phase in rites of passage could be called the liminoid or quasiliminal in Turner's terms. The liminoid is related to the ritually liminal, but it is not identical with it. The main difference is that the liminoid is produced and consumed by individuals and the liminal is believed by the members of society to be of divine origin and is to its nature anonymous. The limi- 
noid is also fragmentary compared to the liminal. Often elements of the liminal have been separated from the whole to act individually in specialized fields like art. (TURNER and TURNER 1978: 253). In art, popular culture, entertainment and tourism products are made for consumption by individuals and groups that promise to remove the consumer away from the everyday experience. They promise a transition into a stage that resembles he liminal for a limited time-span. The attractiveness of mass tourism lies in the possibility to be transported and transformed for a moment into the liminoid where "everything is possible". (SELÄNNIEMI 1996).

When tourists enter the liminoid some changes take place. Normal social time stops in the marginal state of liminality, and it seems to stop also in the liminoid south. People normally confined to the everyday timetables and routines forget the lapse of time and sleep late, eat whenever it suits them, follow no or flexible time schedules, party until they drop and so on. One of the freedoms of the "south" is that you do not have to do anything (SELÄNNIEMI 1996). Social antistructure or the so called communitas - undifferentiated, democratic, direct, and spontaneous social bonds or contacts - is characteristic of liminality. Communitas relieves the individuals from following the common norms. This has to be a temporary state so that society can continue its organized existence. (TURNER and TURNER 1978: 249-250).

If the "south" is understood to be a liminoid "play-zone" for the tourists, it becomes obvious that the cultural and geographical location of this pleasure periphery has only marginal importance. In fact, it seems that the more placeless the destination is, the easier it is for the tourist to break away from everyday life. In this liminoid "south" people behave in ways they wouldn't normally do at home. This could be interpreted as a result of the antistructure of the "south" that entices the latent Other in the tourist's self to come forth. On holiday the anti-self that drinks, hooliganizes, forgets safe sex etc. or an ideal self that is social, sensitive and creative may take over. These selves may also alternate in the same person (SELÄNNIEMI 1996).

In Finnish mass tourism to the "south", i.e. the Mediterranean region and the Canary Islands, it seems to be more important that you travel than where you travel. The chosen destination is of marginal importance as long as it provides the tourist good opportunities to beach life and partying and that there are ample services for the tourist. In this type of tourism tourists travel more to a different state of being than to a different place. In an analogy to the anthropological theories of transition rites, mass tourists can be understood as striving to free themselves for a limited time-span from everyday life both at work and at home. Leaving home and going on a trip seems to be a prerequisite for some people to attain a desired state of relaxation. This is, of course culturally determined. Only in our western societies has tourism become to such a degree a democratic and common activity that it is seen as a normal way of getting away from everyday for a while. It is positively sanctioned in our culture (cf. SMITH 1989). Thus, people buy time for themselves, their spouses and families, as much as they buy a place to visit, when they walk into a travel agent's office to purchase a mass tourism trip to Rhodes or Playa del Ingles for instance. They buy time that is more their own than the time lived in everyday life, where you have to conform to the clock and the rational rhythm of work that do not synchro- 
nize with the natural rhythms of the body - and, consequently, this tension between the rhythms add another element of stress to our lives (cf. ADAM 1995). The liminoid time of the "south" is like the time of our childhood summers that were always sunny and warm and lasted forever.

\section{SERIOUS PILGRIMS? AUTHENTICITY?}

The anthropological tradition of looking at the tourist's journey as structurally analogous to the transition rite (cf. VAN GENNEP 1960; TURNER 1978; LEACH 1982), as a sacred journey in GRABURN's (1989) words, brings us closer to the tourist and the way she/he experiences the journey. It's not a question about if the tourist really enters a sacred zone or liminality, but a way to analyse and describe the process of transgression in tourism.

If we look at tourism from this perspective we do not have to take into consideration variables like authenticity. If a tourist trip is seen like a temporary exit into a liminoid free-zone, there is no need to examine the authenticity of the attractions or resorts, because the pull factor in this type of tourism is either irrelevant or related to factors not uniquely linked to the place visited. If one wants to avoid the term "liminoid" because its ritualistic and religious implications, one might also describe the destinations in a similar vein as playgrounds for tourists, where people become HUIZINGA's (1950) Homo Ludens and experience the flow (CSIKSZENTMIHÁLYI 1975) of play. Analysing the above described type of tourism as play (cf. COHEN 1985) does not imply that it would be less real in the tourists' experiences - it might be less serious than everyday life or pilgrimage, but the overwhelming nature of play and the experience of flow may provide tourists frequenting the "plastic" and "inauthentic" resorts with rewarding experiences. In sunlust tourism what we experience seems less important than how we experience it. This is exactly the aspect that studies conducted in the authenticity paradigm neglect. By transgressing the boundaries of both the context of our everyday lives and also our everyday selves and entering what can be described as the liminoid the most significant change happens in the way we experience ourselves and the environment. That is why tourists may be fully satisfied with contrived attractions or just lying on the beach while on the trip, but the same thing would not satisfy them in their everyday lives. Thus, tourists are not necessarily out on a quest for the authentic, except maybe for the authentic Self (BROWN 1996). It is really not a quest, as most tourists are probably unaware of this side of their motivation and experience. The tourist returning for the 28th time to Playa del Ingles does not return because of the destination as such, but because - as David Brown puts it - "authentic pleasure for him may lie in the very inauthenticity of a tourist attraction" (BROWN 1996: 38). What the tourist experiences, be it authentic or inauthentic, might be less important than how it is experienced.

So, what we have is two major points of view in tourism that are clearly related to the backgrounds of both tourists studied and the researchers who study them. Theories and research conducted with the authenticity paradigm in mind produce 
results that explain very well the ocularcentric (URRY 1995), site-oriented (SELÄNNIEMI 1994a; 1995; 1996), middle class touring of sights, but do not give us any reasonable answers when applied to lower middle-class or working class pleasure-seeking, diversionary, image-oriented (SELÄNNIEMI 1994a; 1995; 1996) mass tourism to beach resorts. This type of tourism can be better analysed with what could be termed the ritual paradigm. Neither approach can or should be solely used in any attempt to formulate universal definitions or theories of tourists. What should be done to a larger extent than today, is the use of the emic perspective in tourism research. That way we may still find the missing tourist.

Using the authenticity paradigm and measuring their experiences with the degree of alienation produces exactly the one-eyed views on tourists as superficial nitwits or modern pilgrims that COHEN (1979) warned us about already in the end of the 70's. We need a strong body of tourist research using the emic perspective to find out who the tourists really are, before we can venture into formulating any general statements. That way we might overcome the large number of general statements on the nature of tourism (cf. COHEN 1972; 1974; 1979; GRABURN 1989; KRIPPENDORF 1989; MACCANNELL 1973; 1989; URRY 1990, etc.) that do not pay enough attention to the dynamics and multiplicity of the phenomenon of tourism and especially to the endless variety of the tourists themselves.

We should always keep in mind when using the notion of authenticity that authenticity is always defined by someone or a group of people for somebody according to criteria or consensus in (high) culture. What should be asked is, who defines authenticity and for whom is it defined - is it for locals or tourists, or is it more a question of defining authenticity in order to legitimize the behaviour of those who define it or is it more unselfishly defined for the benefit for the culture as a whole as common heritage, a unifying past? Defining authenticity always involves also political questions of power relations. How is authenticity constructed and why is it defined and constructed? Who has the power and authority to state the authenticity of something and who benefits?

Because of the inherent connection between the notion of authenticity, what is defined as authentic and those who define it - that is the cultural elite or the upper strata of society, the holders of the "good taste" and the keys of power - we cannot argue that the authenticity paradigm would be suitable for a universal tourism theory. The sunlust tourists implicitly but sometimes even explicitly contradict the "good taste", and they do it with good cultural self-confidence. Thus, they contradict also GRABURN's (1983) thought on that people with higher education and position in society tend to choose individual tourism to more unfamiliar places because they have a better cultural self-confidence. But in the culture of the sunlust tourists, roaming the museums of the world and meeting exotic people in strange places might be considered just a waste of time. Instead you could buy value for your money/time and travel to Playa del Anywhere to have a good time. 


\section{LITERATURE}

ADAM, Barbara

1995: Timewatch. The Social Analysis of Time. Cambridge: Polity Press.

ANTTONEN, Veikko

1992: Interpreting Ethnic Categories Denoting "Sacred" in a Finnish and an Ob-Ugrian Context. Temenos 28: 53-80.

BROWN, David

1996: Genuine fakes, in SELWYN, Tom (ed.) The Tourist Image. Myths and Myth Making in TourCOHEN, Erik ism. John Wiley \& Sons, Chichester.

1972: Toward a Sociology of International Tourism. Social Research 39 (1) 164-182.

1974: Who is a tourist? Sociological review 22 (4) 527-555.

1979: A Phenomenology of Tourist Experiences. Sociology 13 (2) 179-201.

1985: Tourism as Play. Religion 15: 291-304.

CSIKSZENTMIHÁLYI, Mihály

1975: Beyond Boredom and Anxiety: The Experience of Play in Work and Games. Jossey-Bass, San Francisco.

DURKHEIM, Emile

1980: [1912] Uskontoelämän alkeismuodot. (The Elementary Forms of Religious Thought.) Helsinki: Tammi.

ELIADE, Mircea

1979: [1958] Patterns in Comparative Religion. London: Sheed and Ward Ltd.

FALK, Pasi

1994: The Consuming Body. London: Sage.

VAN GENNP, Arnold

1960: [1908] The Rites of Passage. Chicago: The University of Chicago Press.

GOMBRICH, E. H.

1979: The Museum: Past, Present, and Future. In: Ideals and Idols. Essays on values in history and in art, pp. 189-294. Oxford: Phaidon.

GRABURN, Nelson H. H.

1983: The Anthropology of Tourism. Annals of Tourism Research 10 (1) 9-33.

1989: Tourism: The Sacred Journey. In: Valene L. SMITH (ed.) Hosts and Guests: The Anthropology of Tourism. Second edition. Philadelphia: University of Pennsylvania Press.

HORNE, Donald

1984: The Great Museum. The Re-presentation of History. London: Pluto Press.

HUIZINGA, J.

1950: Homo Ludens: A Study of the Play Element in Culture. Beacon Press, Boston.

KRIPPENDORF, Jost

1989: The Holiday Makers: Understanding the Impact of Leisure and Travel. Heinemann Professional Publishing Ltd, Oxford

LEACH, Edmund R.

1982: [1961] Rethinking Anthropology. New York: The Athlone Press.

MACCANNELL, Dean

1973: Staged Authenticity: Arrangements of Social Space in Tourist Settings. American Journal of Sociology 79 (3) 589-603.

1989: [1976] The Tourist: a new theory of the leisure class. New York: Schocken Books.

SCHMIDT, Catherine Joanne

1991: [1980] Tourism: Sacred Sites, Secular Seers. Ann Arbor: University Microfilms International.

SELÄNNIEMI, Tom

1994a: Pakettimatka pyhään paikkaan - suomalaisturistit Ateenassa (A Charter Trip to a Sacred Place - Finnish Tourists in Athens). Jyväskylä: Jyväskylän yliopisto, etnologian laitos, tutkimuksia 25

1994b: Touristic Reflections on a Marine Venus. An Anthropological Interpretation of Finnish Tourism to Rhodes. Ethnologica Fennica 22: 35-42.

1995: Mennään etelään - suomalaisturistit liminoiditilassa. In: Matkailu alueellisena ilminunä. eds. Seppo Aho ja Heli Ilola. Oulun yliopisto, Pohjois-Suomen tutkimuslaitos 197-210. 
SELÄNNIEMI, Tom

1996: Matka ikuiseen kesään. Kulttuuriantropologinen näkukulma suomalaisten etelänmatkailuun (A Journey to the Eternal Summer. The Anthropology of Finnish Sunlust Tourism). Helsinki: SKS.

SHIELDS, Rob

1991: Places on the Margin. Alternative geographies of modernity. London: Routledge. SMITH, Valene L.

1989: Introduction. In: Valene L. SMITH (ed.) Hosts and Guests: The Anthropology of Tourism. Second edition. Philadelphia: University of Pennsylvania Press.

TURNER, Victor

1978: [1974] Dramas, Fields, and Metaphors. London: Cornell University Press.

TURNER, Victor and TURNER, Edith

1978: Image and Pilgrimage in Christian Culture. Columbia University Press.

URRY, John

1990: The Tourist Gaze: leisure and travel in contemporary societies. London: Sage.

1992: The Tourist Gaze "Revisited". American Behavioral Scientist 36 (2) 172-186.

VEIJOLA, Soile, and JOKINEN, Eeva

1994: The Body in Tourism. Theory, Culture \& Society. 11 (1) 125-151. 